\section{FOR GRASS-SPOTTING SWAGMEN}

\section{The Grasses of Central Australia}

\section{By M. Lazarides. Pp. $x i+282$.}

University: Canberra, March 1970.) \$10.0.

Mr Lazarides provides a valuable catalogue of the grass resources of the arid area of central Australia. Designed for use primarily by non-specialist taxonomists, his book comprises a concise, lucid account of the land and vegetation types in the area, followed by an extensive treatment of the grasses.

Grasses make up most of the forage, and must be adequately known before improved management policies can be effected. In an area so inimical to plant growth, efficient exploitation, or conservation, of the grass flora is urgent, and rests on better knowledge of the taxonomy and ecology of constitient species. Lazarides offers a sound guide to both, and his work must be a spur to further research. Though conditions here are so inhospitable, it is galling for a British grass-spotter to note that the grass flora is richer than that of Britain. Many species show fascinating feromorphic adaptations.

The taxonomic treatment of the grasses is preceded by a short, illustrated account of the morphology of the grass plant. The attempt made to simplify this complex subject, without any bending of the facts, is well done. There is a clear generic key.

Descriptions of species occupy most of the book. Each consists of a general account of habit, with notes on occurrence, distribution and forage value, followed by a detailed "botanic description" of the reproductive morphology. There are good photographs of almost all species, often showing spikelet details. Accounts are rendered less awesome, perhaps, to the non-taxonomist, by relegation of nomenclatural details and citations to an appendix.

Minor criticisms which can be levelled at this book arise from the author's praiseworthy attempt to write for a wide audience. There is much to be said for his alphabetical arrangement of genera and species, but could not one page be spared for listing genere into tribes? The first item in the species descriptions is the common name, followed by the Latin binomial. This may make for readier reference by pastoralists, but the author confesses that to achieve this he invented many common names. Regrettably, these are not identified for the sake of later folk studies. They are merely English names which may become common only through the relentless action of natural selection. Brawny cattlemen, perceiving Eragros. tis from their galloping steeds, may scorn to cry "Cuming's love-grass" !

This notable contribution to the literature of the Australian arid regions is a desideratum for all botanical swagmen.

P. M. SMITH

\section{PLANT CHEMISTRY}

Phytochemical Phylogeny

Edited by J. B. Harborne. (Proceedings of the Phytochemical Society Symposium, Bristol, April 1969.) Pp. xiii + 335. (Academic: London and New York, June 1970.) $110 s ; \$ 5.50$.

Tris volume is the latest in the series devoted to the annual symposia of the Phytochemical Society. The book has a wide sweep with articles ranging from "The Origin of Plants" by P. Echlin, to "Secondary Constituents of Aquatic Angiosperms" by J. W. McClure, taking in en route such widely divergent topics as the controversial relationship between bacteria, blue-green algae and chloroplasts (N. G. Carr and I. W. Craig) and the straight organic chemistry of modern and fossil plant resins (B. R. Thomas). Two important contributions come from the Cell Research Institute and Department of
Botany, The University of Texas, Austin, the birthplace of modern phytochemistry in the United States; these contributions "Molecular Approaches to Population Problems at the Infraspecific Level" (B. L. Turner), and "Infraspecific Variation of Sesquiterpene Lactones in Ambrosia ..." (T. J. Marbry) demonstrate how a beaver. like accumulation of data can be used imaginatively to open up now aspects of phytochemical phylogeny. R. L. Watts contributes a thoughtful and readable study of the basic principles, both genetic and biochemical, which underly the importance of studying proteins in relation to plant phylogeny. It is an appropriate time to spell out the reasons for continued studies on amino-acid sequences, now that sequencing is becoming almost a routine performance in modern laboratories devoted to protein chemistry. Watts's contribution is followed by a description by D. Boulter et al. of their sequence studies on cytochromes $c$ from higher plants.

Both Echlin and Chaloner and Allen (palaeobotany and phytochemical phylogeny) point out the dangers which can befall the unwary in dealing with palaeobiology; for example, the ease with which it is possible to confuse artefacts with microfossils and the danger in ascribing the origin of a biochemical extracted from a coaly residue to the source plant: it could be a product of microbial degradation which had occurred before fossilization. Other chapters are concerned with sporopollenin (Shaw), the peculiar and extremely resistant polymer of the pollen wall which is thought to arise by polymerization of pollen carotenoids; with lipids of various photosynthetic organisms (B. W. Nichols), and with environment and enzyme evolution in plants (H. W. Woolhouse), a subject which needs considerably more study before its full implications are apparent. Finally, but by no means least, is a mature article by S. Bartnicki-Garcia on the importance of cell wall composition in fungal phylogeny; in relation to this his final conclusion that "Barring an unforeseen breakthrough in palaeomycology, the use of morphology in conjunction with biochemical data represents the only hope for reconstructing key events in the evolutionary history of the Fungi", is particularly significant.

I congratulate the partieipants in producing such an effective series of reports: the book represents phytochemistry at its best and any non-specialist reading this book is bound to be impressed by the distance modern phytochemistry has travelled during the past decade. The phytochemist of the $1970 \mathrm{~s}$ is a person of wide interests who is successfully responding to the challenge of the new ideas developing in biology and chemistry, and who is meeting fresh problems with the intelligent use of modern equipment ranging from the mass spectrometer to the computer.

The indefatigable secretary of the Phytochemical Society, J. B. Harborne, has edited this volume with his usual professional thoroughness and has included four indices: author, chemical compound, genus and species, subject. The book seems singularly free from factual errors, although it seems inevitable that a book I review will have a carotenoid structure wrong (p. 5). The production of the book is up to the publisher's usual high standard.

T. W. GOODWIN

\section{ELECTROCHEMISTRY}

\section{Modern Electrochemistry}

An Introduction to an Interdisciplinary Area. By John O'M. Bockris and Amulya K. N. Reddy. Vol. 1: Pp. xxxii+1-622. 165s. Vol. 2: Pp. xxvii +623-1432. 190s. (Macdonald: London, July 1970.)

These two substantial volumes provide a novel and stimulating approach to the teaching of electrochemistry 